\title{
Implementation of the Character Building Training (CBT) Program in Character Development of Students of the State Islamic University of Alauddin Makassar
}

\author{
Suhardiman; Supadi; Siti Zulaikha \\ Department of Education Management, Universitas Negeri Jakarta, Indonesia \\ http://dx.doi.org/10.18415/ijmmu.v8i10.3132
}

\begin{abstract}
The purpose of this study is to describe the model for planning, implementing, and evaluating training, as well as the character to be formed through these activities. This study uses a qualitative method. Methods of data collection in the form of interviews and documentation. The approach used is a pedagogic, psychological, and managerial approach. Purposive sampling is the starting point for researchers to determine informants. There are two sources of data used, namely primary data, obtained from data sources or informants involved in the implementation of the Character Building Training (CBT) UIN Alauddin Makassar. Secondary data, the researchers quoted from books, especially books and modules of Character Building Training (CBT) UIN Alauddin Makassar, theses, scientific journals and online, scientific magazines, and various relevant references with the title of the thesis. The results of this study indicate that character education is the development of moral education. Morality comes from the Supreme Absolute while character education is based on religious values, culture, and state ideology. The implementation of character education activities at the Character Building Training (CBT) UIN Alauddin Makassar requires support in the form of policies, a conducive academic atmosphere, and a thorough evaluation of student character building. The implication of the research shows that character education at CBT UIN Alauddin Makassar with a dense volume of activities will give birth to enlightened generations with an increasing number of alumni.
\end{abstract}

Keywords: Character Building Training (CBT); Students' Character; University

\section{Introduction}

The era of globalization is like a wave that rolls into all aspects of human life, affecting the social order in this modern age. Culture, economy, and other social spaces. Indonesia, with its cultural diversity and diverse national characteristics, is also affected by various ideological and cultural offerings that seem to contain liberalization (Untari, 2020).

Education as a means of developing potential as well as the order of human life has a very important and effective function and purpose in the formation of human personality and character. The functions and objectives of Indonesian national education are emphasized on the formation of a strong national character as the basic capital in building a high-level civilization. Thus, the existence of a nation is largely determined by its character. Only a nation that has a strong character can make itself a dignified nation and is respected by other nations (Kusniati, 2020). A great nation is a nation that has a strong character side by side with 
high competence, which grows and develops from a meaningful and enjoyable education and an environment that applies good values in all aspects of national and state life. Only with a strong character and high competence will the national identity become solid, collaboration and national competitiveness will increase so that it can answer various challenges in the 21 st-century era. For this reason, national education must focus on strengthening character in addition to competency formation (Ministry of Education and Culture of the Republic of Indonesia). Indonesia, 2017).

Education is an inseparable part of human life. Since in the womb a baby has experienced a touch of education through intake and touch of love. What happens to the mother's mind can also affect the baby's mental development (Jalaluddin Rakhmat, 20(Hasiana, 2015)10).

Education is a very important presence in the history of human civilization. Education will always be present as the spearhead of human awareness and the progress of the nation and state, of course, seen from the quality of education (Wantika, 2017).

The Character-Building Training Program is a student development program organized by Alauddin Makassar State Islamic University which has been ongoing since 2012. The Character-Building Training Program is one of three programs under the Character Building Program (CBP). One of the goals of CBT is to provide comprehensive insight to students about the importance of developing self-character based on cultural, Islamic values which include intellectual, emotional, moral, social, and spiritual aspects (Sugara \& Mutmainnah, 2020).

A program will achieve its goals when the program is implemented. To implement a public policy, there are two choices of steps that exist, namely directly implementing it in the form of a program or through the formulation of derivative policies or derivatives of these policies. In simple terms, implementation can be interpreted as implementation or application. Browne and Wildavsky, argue that implementation is an extension of activities that adjust to each other. Meanwhile, Schubert suggests that implementation is an engineering system (Usman, 2002)

The definition of implementation above when associated with policy is that the policy is not only formulated and then made in a positive form such as law and then silenced and not implemented or implemented but a policy must be implemented or implemented to have the desired impact or goal. Policy implementation is an effort to achieve certain goals with certain means and in a certain time sequence. (Sopian effendi, 1989). Regarding the CBT program, several researchers have researched it further, such as the research conducted by Rahmatilah with the title "Character Building Training (CBT) Development for UIN Alauddin Makassar Students" 2015. This study discusses the strategy of fostering Character Building Training (CBT). for students of UIN Alauddin Makassar. The results of this study indicate that the CBT development process for UIN Alauddin Makassar students begins with mapping students in groups, each representing a faculty. This coaching model uses an adult education pattern whose characteristics are the emergence of an exchange of opinions, the occurrence of reciprocal communication, a fun and challenging learning atmosphere, prioritizing the role of students, mutual respect for opinions, and mutual trust between supervisors and students (Setianingsih, 2019).

Character education in several countries has received priority and has been developed since primary education. These countries say, China and Japan, have had a strong character to build their individual and country. Meanwhile, in Indonesia since the 2000s this has begun to be discussed. Chapter II Article 3 of the Republic of Indonesia Law No. 20 of 2003 concerning the National Education System states that national education functions to develop capabilities and shape the character and civilization of a dignified nation in the context of educating the nation's life, aiming at developing the potential of students to become human beings who believe and fear God. The Almighty has a noble character, is healthy, knowledgeable, capable, creative, independent, and becomes a democratic and responsible citizen. This shows that education in schools must be able to form a better character. Because when students have reached the "high" level, it means that the education they take has exceeded the level of education of other students. And being a student means automatically signing a work contract to make a real contribution to society, the nation, and the country. 
Some of the factors that cause low character education are: First, the education system emphasizes less on character building, but places more emphasis on intellectual development. Second, environmental conditions do not support the development of good character. Thus, this nation has long had habits that are not conducive to building a superior nation. So character education is currently considered important and urgent (Hidayatullah, 2010). However, the implementation of character education has not been systematically and concretely implemented in schools according to Clara (in Eva Meizara 2016). Meanwhile, according to the Big Indonesian Dictionary, the character is defined as psychological, moral, or character traits that distinguish a person from others.

Psychologically and socio-culturally, character formation in individuals is a function of all individual human potentials (cognitive, affective, cognitive, and psychomotor) in the context of sociocultural interactions (in families, schools, and communities) and lasts a lifetime. Character configuration in the context of the totality of the psychological and sociocultural processes can be grouped into the heart (spiritual and emotional development), thought (intellectual development), sports and kinesthetic (physical and kinesthetic development), and sense and intention (affective development) and creativity development). Based on the discussion above, it can be emphasized that character education is an effort that is designed and implemented systems to help students understand the values of human behavior related to God, oneself, fellow humans, the environment, and nationality which are manifested in thoughts, attitudes, and behaviors. feelings, words, and actions based on religious norms, laws, etiquette, culture, and customs.

Students are an intellectual elite group. They are the ones who have a big role in changing the way of thinking of the Indonesian people to respect traditions, culture, and historical sites inherited from their ancestors. This heavy work will not be carried out if the status of "student" is only used for prestige and following trends or fashions. From here, students must have a strong character so they don't get carried away too far and leave their own culture. That character is to be a student who has strong moral principles and a critical and constructive way of thinking. Character is defined in the Complete Indonesian Dictionary as psychological, moral, or character traits that distinguish a person from others, character, and character. Thus, students with character mean students who have mental qualities, moral strength, morals, or character that come from values, and have beliefs that are embedded in the soul so that a special personality is attached to them.

Various efforts have been made by the government in shaping students into human characters. The first President of the Republic of Indonesia has exemplified the importance of building national identity through the concept of national and character building. The same can be seen from Ki Hajar Dewantoro's statement that education is an effort to advance the growth of a child's character, mind, and body. The parts should not be separated so that we can advance the perfection of our children's lives. Over time, the models and forms of character education carried out by various formal educational institutions from elementary to tertiary levels are increasingly varied.

These efforts aim to produce Indonesian human resources with character, noble character, competence, creativity, and responsibility. The idea of character education emerged as a response to the weakness of education in building Indonesian people with character. The efforts of formal educational institutions to balance the affective, cognitive, and psychomotor domains/skills of students are always attempted, but in fact, excessive emphasis on the development of the cognitive side of students has an impact on the imbalance of attention to developing the affective side, meaning that the affective domain is not touched properly compared to with the other two domains.

As a result, the output has very good hard skills but has problems on the soft skill side. The imbalance of hard skills and soft skills often causes anarchic actions and social conflicts that penetrate almost all lines of people's lives such as declining moral values, abuse of authority by state officials so that the practice of corruption is no longer something to be hidden and even seems to be shown in almost all of our government agencies. 


\section{Research Method}

This research is categorized as descriptive research because the approach taken is through a qualitative approach. Bogdan and Taylor as quoted by Moleong (2014), define a qualitative approach as a research procedure that produces descriptive data in the form of written or spoken words from people who can be observed.

Arikunto, et al (2006), stated what is meant by descriptive research, namely "research that is not intended to test certain hypotheses, but only describes "what is" about a variable, symptom or situation."

researchers use different data collection techniques to obtain data from the same source. Researchers used participatory observation, in-depth interviews, and documentation for the same data source simultaneously (Sugiyono, 2019).

\section{Result and Discussion}

Research findings are obtained through observations, interviews, and document analysis related to the research sub-focus that has been determined, namely:

Planning of Character-Building Training (CBT) Program on Character Development of Alauddin University Makassar Students.

The planning stage of the Character Building Training (CBP) program which of course has a lot of philosophy and ideology based on synergy with the educational orientation in the UIN Alauddin Makassar campus environment. At the stage of organizing the training, of course, there is a plan.

Before a certain batch of students finishes the training in stages, new students in the following year will be in line to participate in activities. It was recorded that until December 20, 2013, the CBT alumni of UIN Alauddin Makassar had reached 4300 people who were absorbed in 19 batches.

Based on the results of interviews with various respondents who have contributed to the implementation of CBT, including Prof. Saharuddin Usman, provided a statement related to planning as follows;

Before the training is carried out, several things need to be prepared including the committee, decree, budget and resolution, and all things that will be needed before conducting the training. (Saharuddin Usman; 2021).

To support the implementation of the training, the author also needs to describe several elements that have no less important role in the implementation of the training. The elements in question are the coaching team, mentor/instructor team, resource persons, administrative staff. The condition of each of these elements can be noted as follows:

\section{a. Mentor}

The Coach Team is a team formed and assigned by the Chancellor of UIN Alauddin Makassar who recruits mentors/instructors through training of trainers (TOT). The Coaching Team is permanent.

\section{b. Source Person}

The resource persons involved in the implementation of character education at CBT UIN Alauddin Makassar consist of two elements, namely; regular resource persons and guest resource persons. The resource persons are still educators within the scope of UIN Alauddin Makassar who have the status of lecturers and are a team of coaches. 


\section{c. Facilities and Infrastructure}

Facilities and infrastructure are supporting factors and are no less important in the implementation of activities. Seeing that the implementation of CBT activities at UIN Alauddin Makassar occupies two different locations, namely indoor class and outdoor class, the facilities, and infrastructure at both locations require improvement from various sides.

Implementation of the Character Building Training (CBT) Program on Character Development of Alauddin University Makassar Students

The implementation of the Character Building Training (CBT) program at the UIN Alauddin Makassar campus was held based on the planning concept that had been prepared by CBT functionaries, which used a character education learning model at the UIN Alauddin Makassar campus. The stages of implementing the training held which will be described based on the data obtained by the researcher are as follows;

\section{a. Pra-Training}

The first step in the effort to build character through CBT activities at UIN Alauddin Makassar is to record the number of students who will take part in training activities. The percentage of the number of new students with the volume of CBT activities at UIN Alauddin Makassar was formulated through a meeting between the management of CBP UIN Alauddin Makassar and the university leadership. Implementation information is conveyed to the faculty and then the faculty conveys it intensely to each student.

\section{b. Implementation of Training}

The training at CBT UIN Alauddin Makassar was carried out for three days and two nights and used two different classroom conditions or places. The conditions for the implementation of the training can be described as follows:

\section{Indoor class}

The first activity carried out after the official opening of the training by the university leadership was ta'âruf (introduction). The introductory segment starts with the trainer introducing the coach, then the coach introduces the mentor.

The next session introduces the participants to the participants. The material presented in the introductory segment concerns duplication in general including, name, regional origin, work unit, interesting experience, status, and other general matters.

The ta'âruf segment was placed as the beginning of the implementation of this activity to dilute the formal atmosphere and create an atmosphere of intimacy between the trainer, the mentor/instructor team, and the participants. The term in the implementation of the training is to build self-relationships with oneself and self-relationships with others.

\section{Outdoor class}

After receiving the material in the indoor class, it is followed by receiving the material in the outdoor class. The outdoor class was held in the natural charm hill of Bilaya village, Patallassang subdistrict, Gowa district. Acceptance of outdoor class material is included in the main material section of the training implementation. Outdoor class is a student's self-awareness in building their relationship with their cosmic voice (the universe). 
Participants arrived at dusk and entered the time of Maghrib. Nurkhalis stated that the characteristic of CBT activities at UIN Alauddin with other activities is that CBT activities are full of symbols and philosophical values.148 If students arrive at a location, it is not uncommon for students to do no activities first, such as taking selfies, selfies, or joking. This is not the case at CBT UIN Alauddin Makassar.

Evaluation and Follow-up of the Character Building Training (CBT) program in Character Development of Alauddin Makassar State Islamic University Students

After participants take part in indoor and outdoor class activities, participants will be returned to their respective faculties to participate in academic activities. CBT Alumni appoints an alumni president as the representative for the participants. Post-training mentors who are appointed lecturers from each faculty have the responsibility to continue to supervise and evaluate the participants' self-resolution. Supervision and evaluation are carried out for 40 (forty) days after training.

Muhammad Sabri AR, stated, the number forty is not simply a time setting, but the number forty has a deep meaning, namely, forty is the pinnacle of success and maturity of human beings emotionally and mentally. Forty is the age of the Prophet Muhammad. appointed by Allah SWT. as an apostle and follow the journey with Jibril to Masjid al-Aqs \}a and to the highest layers of heaven. So it is hoped that with the coaching for forty days the seeds of character instilled in students can grow and be useful until they return to society and the nation.

The number forty is the number of seconds of the nation's resolution which was read by the figure of the Proclaimer of the nation Ir. Soekarno and Moh. Hatta and be heard to the participants. The accumulation of physical resistance of the Indonesian people in seizing independence from the shackles of the colonialists for 350 years ended in approximately 40 seconds. Nurkhalish believes that through the 40 days, it is hoped that the character seeds obtained from the training will be able to become patterns and be consistent in students.

After the training process is carried out for 3 days with a periodic system which is carried out on Friday afternoons and ends in the next 3 days. Aspects that are considered after training are of course a priority in the implementation of training because this stage is an evaluation. There are several supporting and inhibiting factors after training.

Supporting and Inhibiting Factors in the Implementation of Character Building Training (CBT) in Character Building Students

The results of this study indicate that some of the supporting factors of CBT are its various benefits, including the synergy of the vision and mission of UIN Alauddin Makassar which prioritizes spirituality, the materials used in the training implementation have quality and the implementation of varied and innovative activities and also improves the quality of worship of the training participants.

And the inhibiting factor is the quality of mentors and inadequate facilities and infrastructure which then affect the implementation of the training.

Limited training time and colliding with other academic activities. The motivation of the training participants caused by the socialization carried out by the implementing committee was less than optimal.

\section{Conclusion}

Listening to the discussion of the research results, the authors conclude as follows:

Implementation of the Character Building Training (CBT) Program in Character Development of Students of the State Islamic University of Alauddin Makassar 
1. The planning stage in pre-training is to fulfill administrative and cost readiness as well as the publication of information to training participants by seeking various media advantages and the synergy of various tools that can connect the implementers and participants.

2. Implementation of activities, building student character through activities at CBT UIN Alauddin Makassar has the main obstacle, namely Status. This has an impact on the readiness of facilities and infrastructure for the implementation of activities. Physical facilities include accommodation for participants and mentors, limited mosque capacity, ablution facilities, and other supporting facilities. Non-physical is more focused on the managerial implementation of activities (curriculum, human resources, and financing). The supporting factor lies in the mindset of viewing CBT UIN Alauddin Makassar other than as a state celebration, but the character is a solution in responding to the turbulence of the modern human humanitarian crisis. This the author considers an important point because it departs from the mindset, constructively all endeavors and other activities are important to be carried out.

3. The evaluation stage is of course by presenting a new atmosphere and the main concept before the implementation of the training. The characters formed in the implementation of the training are honest, trustworthy, responsible (thoughtful), friendly, caring (taste/intention), critical, creative, thinking (thought) and clean, healthy, disciplined, sporty (sports).

\section{References}

Aynur Pala, THE NEED FOR CHARACTER EDUCTION, Internatinal journal of Social Sciences and Humanity Studies. Vo. 03, No. 02, 2011.

Budimansyah, dkk., (2010) Model Pendidikan Karakter di Perguruan Tinggi. Bandung: Universitas Pendidikan Indonesia.

CBP UIN Alauddin Makassar, "Visi Misi Bidang Character Building Training (CBT)", CBP UIN ALAUDDIN Online, cbp.uin-alauddin.ac.id/index.php/2014-10-29-02-04-2/2014-10-29- 02-1050/visi-misi-bidang-character-building-training-cbt (Diakses pada 29 April 2018).

Dewi, E,M,P. (2016). Gambaran Karakter dan Aspirasi Terhadap Pendidikan Karakter Pada Mahasiswa Psikologi Universitas Negeri Makassar. Jurnal Ilmiah Psikologi, Vol. 7 No. 2, hlm 76-91.

Djailani AR., "Strategy Character Building of Students at Excellent Schools in the City of Banda Aceh", IOSR Journal of Research \& Methods in Education, Vol I (5), Mai-Juni 2013, hh. 51-52.

Doni Koesoema, (2010) Pendidikan Karakter: Strategi Mendidik Anak di Zaman Global, Jakarta: Grasindo.

Effendi, Sofian, (1989), Alternatif Kebijaksanaan Perencanaan Administrasi: SuatuAnalisis Retrospektif dan Prospektif (Yogyakarta: UGM Monograph)

Fathur Rokhman, dkk., "Character Education for Golden Generation 2045 (National Character Building for Indonesian Golden Years)" Procedia-Social and Behavioral Sciences, Vol. 141, Agustus 2014, hh. 1161-1165.

Franz Magnis-Suseno, (2010). Dalam Acara Sarasehan Nasional Pengembangan Pendidikan Budaya dan Karakter Bangsa.

Ghamrawi, N. A. R., Ghamrawi, N., dan Shal, T. Perception of Character Education: The Case of Lebanese School Leaders. Open Journal of Leadership, Vol. 4, 2015

Hasiana, I. (2015). mengembangkan karakter anak usia dini melalui permainan tradisional. Buana Pendidikan: Jurnal Fakultas Keguruan Dan Ilmu Pendidikan, 11(21). 
Hibur Tanis, "Pentingnya Pendidikan Character Building dalam Membentuk Kepribadian Mahasiswa", Journal of Character Building Development Center BINUS University Vol. 4 (2), Oktober, 2013, hh. 1212-1219.

Hidayatullah, F. (2010). Pendidikan karakter: Membangun peradaban bangsa. Surakarta: Yuma Pustaka.

Hidayatullah, Guru sejati, Membangun Insan Berkarakter Kuat dan Cerdas (Cet. III; Surakarta: Yuma Pustaka)

Ilyas Ismail, Muhammad. Buku Daras Pendidikan Karakter Bangsa Suatu Pendekatan Nilai, Makassar: Alauddin University Press, 2012.

Jon C. Barch, Rachel Harris, dan David L. Bonsall, Leadership Education as Character Development: Best Practices from 21 Years of Helping Graduates Live Purposeful Lives Journal of College \& Character, Vol. 13 (4), 2012

Ki Hadjar Dewantara, (2004) Pendidikan, Yogyakarta: Majelis Luhur Persatuan Taman Siswa.

Kusniati, T. (2020). Meningkatkan Hasil Belajar Operasi Hitung Bilangan Pecahan Dengan Kartu Bilangan Siswa Kelas VI SDN 3 Mangliawan Kecamatan Pakis Kabupaten Malang. Buana Pendidikan: Jurnal Fakultas Keguruan Dan Ilmu Pendidikan, 16(29), 52-64.

Lickona, T. (2004). Character matters. New York: Touchstone Rockefeller Center

Lukman Abu, Mahani Mokhtar, Zainudin Hassan \& Siti Zakiah Darmanita Suhan, "How to Develop Character of Madrassa Students in Indonesia, Journal of Education and Learning, Vol. 9, 2015.

Muhammad Amri, Implementasi Program Character Building Training (Studi Kasus Mahasiswa Pendidikan Agama Islam Angkatan 2013), Jurnal Inspirasi Pendidikan, Vol. 5 No. 1, 2016.

Muhammad Yaumi, (2012) Pilar-Pilar Pendidikan Karakter, Makassar: Alauddin University Press.

Nugroho, Riant. (2009) Public Policy Edisi Revisi. Jakarta, Elex Media Komputindo.

Rahmatilah, Pembinaan Character Building Training (CBT) Bagi Mahasiswa UIN Alauddin Makassar, http://repositori.uin-alauddin.ac.id/id/eprint/3207. 26 Juli 2017

Ratna Megawangi, (2004) Pendidikan Karakter: Solusi yang Tepat untuk Membangun Bangsa, Jakarta: Indonesia Heritage Foundation.

Samani Muchlas \& Hariyanto, (2011) Konsep dan Model Pendidikan Karakter, Bandung: PT Remaja Rosdakarya.

Saptono. (2011). Dimensi-dimensi pendidikan karakter. Jakarta: Erlangga.

Setianingsih, D. (2019). Implementasi Nilai Karakter Dan Moral Mahasiswa Melalui Tutor Sebaya Kepada Mahasiswa Berkebutuhan Khusus. Buana Pendidikan: Jurnal Fakultas Keguruan Dan Ilmu Pendidikan, 15(27), 8-15.

Setyabudi Indartono, The Effect of-Learning on Character Building: Propostion for Organizational Behavior Course, Jurnal Pendidikan Karakter, No. 1. Vol. 01, 2011.

Sitti Mania dan Hasanuddin, Evaluasi Pelaksanaan Program Character Building Training di Universitas Islam Negeri Alaudin Makassar. Islamic Counseling: Jurnal Bimbingan dan Konseling Islam, Vol. 2, no. $01,2018$.

Sri Nawanti, (2012) Pendidikan Karakter, Yogyakarta: Familia.

Sugara, H., \& Mutmainnah, F. (2020). Peran Guru Ppkn Dalam Membangun Karakter Bangsa Sebagai 
Respon Dan Tantangan Abad KE-21. Buana Pendidikan: Jurnal Fakultas Keguruan Dan Ilmu Pendidikan, 16(29 SE-), 16-30. https://doi.org/10.36456/bp.vol16.no29.a2266.

Sulhan, N. (2010). Pendidikan berbasis karakter. Surabaya: PT JePe Press Media Utama.

Undang-Undang No. 20 Tahun 2003, Tentang Sistem Pendidikan Nasional. Bab II Dasar, Fungsi, Tujuan. Pasal 3 sebagai Fungsi Pengembangan Kemampuan Watak dan Karakter Kehidupan Bangsa.

Untari, S. K. (2020). Kreatifitas Guru Dalam Menyongsong Pembelajaran Masa Pandemi Covid-19. Buana Pendidikan: Jurnal Fakultas Keguruan Dan Ilmu Pendidikan, 16(30s), 49-53.

Wantika, R. R. (2017). Pembelajaran Kooperatif Tipe TAI Berdasarkan Teori Beban Kognitif. Buana Pendidikan: Jurnal Fakultas Keguruan Dan Ilmu Pendidikan, 13(23), 41-46.

\section{Copyrights}

Copyright for this article is retained by the author(s), with first publication rights granted to the journal.

This is an open-access article distributed under the terms and conditions of the Creative Commons Attribution license (http://creativecommons.org/licenses/by/4.0/). 